eCommons@AKU

June 2018

\title{
Training pediatric mechanical ventilation to front line pediatric physicians
}

Qalab Abbas

Aga Khan University, qalab.abbas@aku.edu

Lubaina Ehsan

Aga Khan University

Humaira Jurair

Aga Khan University, humaira.jurair@aku.edu

Anwarul Haque

Aga Khan University, anwar.haq@aku.edu

Follow this and additional works at: https://ecommons.aku.edu/

pakistan_fhs_mc_women_childhealth_paediatr

\section{Recommended Citation}

Abbas, Q. Ehsan, L., Jurair, H., Haque, A. (2018). Training pediatric mechanical ventilation to front line pediatric physicians. Journal of the College of Physicians and Surgeons Pakistan: JCPSP, 28(6), 492.

Available at: https://ecommons.aku.edu/pakistan_fhs_mc_women_childhealth_paediatr/375 


\section{Training Pediatric Mechanical Ventilation to Front Line Pediatric Physicians}

Mechanical ventilation (MV) is one of the defining interventions of critical care medicine helping save millions of patients' lives. ${ }^{1}$ Providing pediatric critical care in Pakistan is a unique challenge because of limited, less prioritised resources and lack of training. ${ }^{2}$ Because of few centres having trained pediatric intensive care unit (PICU) physicians, MV is being managed by residents/ nurses/non-ICU physicians, while MV is not included in their curriculum. ${ }^{3}$ Without proper training, this life-saving machine can be a weapon of "mass destruction".4

Keeping need-demand gap in mind, we designed a halfday course on MV with the aim to train frontline pediatricians on use of MV at 10 tertiary care academic hospitals in two cities of Pakistan; all of these centres had postgraduate pediatric residency programme and mechanical ventilators. Target audience was pediatric trainees, nurses and consultants who were working in PICU, and were actively involved in providing care to children requiring MV. This 4-hour course consisted of didactic lectures covering anatomic and physiologic airways differences in infants and children, concepts and principles of MV, initiation, monitoring, trouble-shooting and liberation from MV in the first half; followed by smallgroup (4-5 persons) hands-on training on MV machine with artificial lung with common case scenarios of acute respiratory insufficiency in the second half. Each course had a written pre- and post-test covering aspects discussed during the course.

A total of 311 participants were trained in 17 courses from July 2013 to December 2016; including 234 pediatric trainees, 26 consultants, and 31 PICU nurses. The mean
$( \pm S D)$ percentage of scores in pre- and post-test were $50.63 \% \pm 27.22$ and $62.12 \% \pm 23.19$, respectively; with an increase in mean percentage of scores in pre- and post-test of $11.49 \%(p<0.001)$. Median of the overall evaluation of the course on a 5-point Likert Scale was 4; the course was excellent. Highest evaluations were given to 'acquired new knowledge', 'time management' and 'objectives of activity were defined'.

Focused educational intervention, like this, increased the knowledge which was unsatisfactory in the pre-test. The translation of this knowledge into practice has the potential of improving clinical outcomes of sick children and saving many preventable deaths.

\section{REFERENCES}

1. Berthelsen PG, Cronqvist $M$. The first intensive care unit in the world: Copenhagen 1953. Acta Anaesthesiol Scand 2003; 47: 1190-5.

2. Riviello ED, Letchford S, Achieng L, Newton MW. Critical care in resource-poor settings: lessons learned and future directions. Crit Care Med 2011; 39:860-7.

3. Haque ALL, Hamid MH, Mirza S, Siddiqui NR, Bhutta ZA. A national survey of pediatric intensive care units in Pakistan. J Crit Care Med 2014; 2014:1-4.

4. McCunn M. Mechanical ventilation: weapon of mass destruction or tool for liberation? Crit Care Med 2003; 31:974-6.

Qalab Abbas 1 , Lubaina Ehsan ${ }^{3}$, Humaira Jurairl and Anwar ul Haque 2

1 Department of Pediatrics and Child Health, The Aga Khan University Hospital, Karachi.

2 Department of Pediatrics, The Indus Hospital, Karachi.

3 Medical Student, The Aga Khan University Hospital, Karachi.

Correspondence: Dr. Qalab Abbas, Assistant Professor, Department of Pediatrics and Child Health, The Aga Khan University Hospital, Karachi.

E-mail: qalababbas@gmail.com

Received: December 16, 2017; Accepted: February 21, 2018. 